\title{
TUBERCULOSIS AND LEPROSY IN ANTIQUITY: AN INTERPRETATION
}

\author{
by
}

\section{KEITH MANCHESTER*}

FOR many years, palaeopathology has been concerned with recording individual examples of disease in earlier peoples. Recent years have shown an increasing interest in the wider view of disease in antiquity, and it is within this context that the discipline of palaeoepidemiology has developed. The interaction of human disease and environment has always been complex. It is doubtful if there is any single disease that can be directly or causally attributed to a specific environmental circumstance. But it is for the palaeopathologist to elucidate the biology of specific diseases in early peoples, and it is for the archaeologist and social historian to elucidate the associated environmental factors.

The present paper outlines a hypothesis concerning the two diseases, leprosy and tuberculosis, and their relation to some aspects of human social evolution.

Tuberculosis is a chronic granulomatous infectious disease caused by bacteria of the genus Mycobacterium. The species is Mycobacterium tuberculosis and, although there are perhaps differing views on taxonomy, the two types of bacillus within this species which are pathologically important to man are the human type and the bovine type. These two are distinguishable in the laboratory and yet are very closely related. Their different clinical manifestations in man are largely due to their usually different portals of entry into the body. The human type gains entry mainly by inhalation of breath from an infected person; the primary site of infection is therefore in the lung. Because it is spread by human to human contact, it is a population density-dependent disease. The bovine type, being primarily a disease of cattle, usually gains entry by the ingestion of infected meat or milk. The primary site of infection is therefore in the gut. The course of the disease may progress from the primary sites, and this progression is of significance for palaeopathological evidence. In the otherwise healthy, wellnourished person with possibly some genetic immunity, the disease may advance no further, but become arrested with the induction of a high degree of immunity. If the infected individual fails to contain, localize, and overcome his primary infection, the bacilli spread to other organs of the body, in addition to local dissemination around the primary site. Although spread to liver, spleen, lymph nodes, and brain does occur, it is the involvement of bone that is of osteoarchaeological significance. The osteoarchaeological evidence of tuberculosis depends mainly on the presence of Pott's tuberculous osteomyelitis of the spine. To a lesser extent, it depends also on the recognition of tuberculous arthritis, typically of the hip or knee joint. The sometimes difficult differential diagnosis of osseous tuberculosis has been discussed by

* Keith Manchester, MB, BS, BSc, FRAI, School of Archaeological Sciences, University of Bradford. 


\section{Tuberculosis and leprosy in antiquity}

\section{Shadomy. ${ }^{1}$}

In American Indian populations, it has recently been shown that bone involvement is not a common phenomenon in tuberculosis; Steinbock ${ }^{2}$ states that bone involvement occurs in five to seven per cent of cases of untreated tuberculosis. With this in mind, and considering the fatalities early in the course of the disease from extensive soft tissue affection, perhaps osteoarchaeology reveals only the tip of the tuberculosis iceberg of antiquity. Morse ${ }^{3}$ has recorded documentary references to tuberculosis in Hindu, Hebrew, Greek, Roman, Arabic, and medieval writings. With this type of evidence, however, there is an even greater possibility of diagnostic error than with skeletal specimens.

If, as the present paper proposes, the tuberculosis history of mankind is bacteriologically biphasic, it is likely that the first tubercle bacillus to cause human disease was of the bovine type. The human type is dependent for its continued existence upon fairly large human communities. Group size in respect to the endemicity of infectious disease has been examined by Cockburn. 4 Using measles, an acute virus infection, as his source, he found that a community size of $1 \frac{1}{2}$ million was necessary for the endemicity of that disease. A much smaller group size is probably necessary for a chronic bacterial infection such as tuberculosis. Black ${ }^{5}$ studied the $^{2}$ incidence of infectious disease in several Amazon Indian tribes and noted that those infections, like tuberculosis, which can persist in individuals for prolonged periods and which have long infectious phases are highly endemic even in isolated tribes. Within this context, the extended population of intergroup contact for the transmission of disease is significant. Obviously, the more frequent and close that contact between separate population groups occurs, the greater is the likelihood of disease transfer between the groups.

Mankind probably obtained its first tuberculosis parasite from infected cattle, and although a close association between man and cattle is a likely prerequisite for such bacterial transfer, this is not necessarily so. Infected meat could have been consumed at any time in man's carnivorous history, assuming, of course, that the disease was present in the hunted herds. But ideas must be based on the available evidence.

The earliest evidence of human tuberculosis is from Egypt and consists of figurines demonstrating the angular kyphosis typical of Pott's tuberculous osteomyelitis of the spine. Several such objects from Nubia and Nagada and dated as early as $3700 \mathrm{BC}$ have been identified by Morse, Brothwell, and Ucko. ${ }^{6}$ Although other diseases are considered possible, a tuberculous model seems the most likely. Undoubted evidence of tuberculosis has been found in a mummy of the XXI Dynasty (1070-946 BC). In

\footnotetext{
${ }^{1}$ H. J. Shadomy, 'The differential diagnosis of various fungal pathogens and tuberculosis in the prehistoric Indians', in J. E. Buikstra (editor), Prehistoric tuberculosis in the Americas, Evanston, Northwestern University Archaeological Program, Scientific Papers Number 5, 1981, pp. 25-34.

2 R. T. Steinbock, Paleopathological diagnosis and interpretation, Springfield, III., Charles C Thomas, 1976.

${ }^{3}$ D. Morse, 'Prehistoric tuberculosis in America', Am. Rev. resp. Dis., 1961, 85: 489-504.

'A. Cockburn, 'Where did our infectious diseases come from? The evolution of infectious disease', in K. Elliot and J. Whelan (editors), Health and disease in tribal societies, (Ciba Foundation Symposium 49), London, Associated Scientific Publications, 1977, pp. 103-113.

${ }^{5}$ F. L. Black, 'Infectious diseases in primitive societies', Science, 1975, 187: 515-518.

- D. Morse, D. Brothwell, and P. J. Ucko, 'Tuberculosis in Ancient Egypt', Am. Rev. resp. Dis., 1964, 90: $524-541$.
} 


\section{K. Manchester}

this, the spinal involvement is present and there is an associated psoas abscess.

Early European evidence of the disease has been suggested in a skeleton of Neolithic date from Heidelberg, but there is doubt about the validity of the diagnosis. Sager et al.' have diagnosed the disease on the typical and specific spinal osteomyelitic changes in a skeleton from Denmark dated to 2500-1500 BC.

It seems, therefore, that at present the earliest evidence of tuberculosis in man probably comes from Egypt. What circumstances at that time and place would facilitate the bacterial transfer from cattle to man?

The earliest evidence to date of animal tuberculosis appears in the Indian elephant. It is known to have infected this species at some time before $2000 \mathrm{BC}$, but the source of the infection is not known. Grmek ${ }^{8}$ suggests that Mycobacterium avium was an evolutionary earlier form of Mycobacterium. It is possible that a mutational change of this avian Mycobacterium enabled its transference to mammalian species. Zeuner' states that, late in Pleistocene times, Indian elephants extended through Mesopotamia to the borders of Asia Minor; therefore animal tuberculosis may have spread through that area at an early period.

But it is probably from the domestic herds that man obtained his bacterium. Bökönyi ${ }^{10}$ has suggested that a single large centre of cattle domestication first developed in the seventh and sixth millennia BC in the north-eastern basin of the Mediterranean. Goat domestication occurred in Asiab, Iran, between 8000 and $7700 \mathrm{BC}$. These cattle and goat herds were presumably a source of food for their keepers. An increased animal population density brought about by herding would favour the spread of infectious disease within herds. Sherratt ${ }^{11}$ proposes that the milking of cattle, firstly for animal food and later for human food, occurred in the fifth millennium BC in Northern Iraq, Syria, and Palestine. This provision of milk food, possibly from tuberculous beasts, may have encouraged the dissemination of tuberculosis amongst herds as well as transference of the disease to humans. By modern analogy, milk as raw food tends to go to young children rather than adults. Just as in later centuries, childhood tuberculosis may have thus occurred, with the production of gut, lymph node, and vertebral involvement. Hence, both infected cattle flesh and milk may have been the vehicles for the transfer of bovine tuberculosis to human populations in the Neolithic period, initially in the eastern Mediterranean area.

Perzigian and Widmer ${ }^{12}$ have noted, with regard to tuberculosis in prehistoric America, that the lesions are largely confined to sedentary agriculturally-based com-

\footnotetext{
'P. L. Sager, M. Schalimtzek, and V. Møller-Christensen, 'A case of spondylitis tuberculosa in the Danish neolithic age', Dan. med. Bull., 1972, 19, 5: 176-180.

'M. D. Grmek, 'La paleopathologie et l'histoire naturelle des mycobacteries', Proc. 3rd European Meeting, Paleopáthology Association, Caen, 1980, pp. 59-64. M. D. Grmek, Les maladies à l'aube de la civilisation occidentale, Paris, Payot, 1983, pp. 291-306.

'F. E. Zeuner, A history of domesticated animals, London, Hutchinson, 1963.

${ }^{10} \mathrm{~S}$. Bökönyi, ‘Animal remains from the Kermanshah Valley, Iran', Br. archaeol. Rep., Suppl., 1977, 34.

"A. Sherratt, 'Plough and pastoralism: aspects of the secondary products revolution', in J. Hodder, G. Isaac, and N. Hammond (editors), Pattern of the past: studies in honour of David Clarke, Cambridge University Press, 1981.

${ }^{12}$ A. J. Perzigian and L. Widmer, 'Evidence of tuberculosis in a prehistoric population', J. Am. med. Ass., 1979, 241: 2643-2646.
} 


\section{Tuberculosis and leprosy in antiquity}

munities, rather than nomadic peoples. Extending from the Near Eastern cradle of tuberculosis, reports of skeletal lesions appear elsewhere; the German and Danish examples have already been mentioned. Brothwell ${ }^{13}$ has noted the late establishment of the disease in Northern Europe, most examples being post-Roman.

The disease was present in Britain at least by the Roman period. Pott's disease has been diagnosed in a skeleton from Poundbury and in a female skeleton of third- to fifth-century date from Queensford Mill. Further specimens, albeit few, have been reported from Anglo-Saxon England. However, the disease may not have been as rare in pre-Conquest England as skeletal evidence suggests, Edward the Confessor introduced the practice of touching for the King's Evil* (scrofula or tuberculosis of the cervical lymph nodes). The exact incidence of tuberculosis in those early years is impossible to determine, but Brothwell ${ }^{14}$ suggests that the disease may have been a serious health threat in Europe by Saxon/medieval times. As Daniel ${ }^{15}$ remarks, "palaeoanthropologists studying bony lesions must recognize that their perspective on tuberculosis is very limited, although it may be the only one available". However, using the London Bills of Mortality, Clarkson ${ }^{16}$ suggests that up to twenty per cent of deaths in London in the non-plague years of the seventeenth century were due to consumption, and though the diagnosis of consumption doubtless included many cases of non-tuberculous pneumonia, the majority of deaths with this diagnosis were probably due to pulmonary tuberculosis. Presumably, therefore, the human-type bacterium was prevalent, bovine-type infection taking second place. By modern analogy, it is also probable that, in addition to this high seventeenth-century mortality, there were many people who had overcome their primary tuberculous infection, survived, and developed immunity to the disease.

Notwithstanding the lack of skeletal evidence from this later period, it would seem that there was a considerable increase in the incidence of tuberculosis in England between the late Saxon period and the seventeenth century. What are the social, economic, and environmental factors which might have contributed to this increase in the late Middle Ages?

First, because infection by the human-type bacillus, notably producing pulmonary tuberculosis, is a population density-dependent disease, the growth of towns may be significant. Indeed, Cockburn ${ }^{17}$ concludes that tuberculosis in its present form cannot have existed before the creation of towns and urban life. Pounds ${ }^{18}$ has suggested that the revival of urban living in Europe gathered momentum from the tenth century, the number of new town foundations reaching a peak in the late thirteenth century. Of

${ }^{13}$ D. R. Brothwell, personal communication, 1983.

* The precise date of the introduction of this term is not known. Gilbertus Anglicus (fl. 1250) stated in his Compendium medicinae, "Scrofula is called the King's Evil because kings cure it" (see Sir Raymond Crawfurd, The King's Evil, Oxford, Clarendon Press, 1911, p. 29).

${ }^{14}$ D. R. Brothwell, 'Palaeodemography', in W. Brass (editor), Biological aspects of demography, London, Taylor \& Francis, 1971, pp. 111-130.

${ }^{15}$ T. M. Daniel, 'An immunochemist's view of the epidemiology of tuberculosis', in Buikstra (editor), op. cit., note 1 above, pp. $35-48$.

${ }^{16} \mathrm{~L}$. Clarkson, Death, disease and famine in pre-industrial England, Dublin, Gill \& MacMillan, 1975.

"A. Cockburn, The evolution and eradication of infectious diseases, Baltimore, Md., Johns Hopkins Press, 1963, p. 221.

18 N. J. G. Pounds, An economic history of mediaeval Europe, London, Longman, 1974, pp. 100, 258-262. 


\section{K. Manchester}

course, this township foundation may merely express a social organization rather than define areas of high population number and density. As Pounds ${ }^{18}$ noted, at the end of the thirteenth century, a period of maximum population growth, very few urban centres had populations in excess of 50,000, and these were mostly in Italy. Perhaps no more than fifteen or twenty towns in Europe as a whole had populations greater than 25,000, the majority having populations of 2,000-10,000. But these figures are not very helpful in the analysis of England. Keil ${ }^{19}$ has commented that few towns, apart from London, had populations in excess of 5,000, and these were Bristol, Norwich, York, Coventry, and Southampton. Green ${ }^{20}$ suggests that a figure of 40,000 may be reasonable for London by the mid-fourteenth century. McNeill21 remarks that, in spite of the increasing importance of towns in Western Europe, townsmen remained a small minority of the entire population until long after the fourteenth century. For disease transfer, however, a larger population than the actual town may be operative. Inhabitants of surrounding villages no doubt visited towns in their business of trade. The expanding markets of the Middle Ages brought people together, their increased contact encouraging the spread of tuberculosis. Perhaps townships and associated rural communities should be regarded as population aggregates acting as a single unit in the dissemination of infectious disease. Following a study of tuberculous lesions in pre-Columbian skeletons from Illinois, Buikstra and $\mathrm{Cook}^{22}$ conclude that a human density-dependent disease is probably related not so much to the size of a local group but to the aggregate size in major centres.

During this time, the Black Death may have exerted opposing influences in the development of tuberculosis. Population depletion after the mid-fourteenth century both in town and countryside may have discouraged its spread. However, a reduction of living standards and consequent health standards may have favoured the diffusion of tuberculosis within the community.

Second, Hilton ${ }^{23}$ has shown for the West Midlands that cattle raising for the butchers' markets of Coventry and elsewhere increased in the fifteenth century. Also, high-yielding dairy cows from the Po Valley were introduced into Northern Europe in the thirteenth century, and it is certain that bovine tuberculosis existed in cattle in Northern Italy at an early stage. As a result of this usage of Italian cattle, tuberculosis amongst domestic dairy herds in Northern Europe may have increased from the thirteenth century. A further aspect of increasing animal husbandry in the Middle Ages is the animal to human contact encouraged by medieval housing design, in which man and animal shared a common dwelling. In such close proximity, the bovine-type bacillus may have gained entry to man by the inhalation route.

What has been attempted so far is to explain a presumed increase in tuberculosis in the Middle Ages in England, for which it is admitted there is, and maybe always will be, little skeletal evidence, by a consideration of the bacteriology of the disease, and the social changes of the time.

19 I. J. E. Keil, personal communication, 1982.

${ }^{20}$ V. H. H. Green, Mediaeval civilisation in Western Europe, London, Edward Arnold, 1971, p. 68.

${ }^{21}$ W. H. McNeill, Plagues and peoples, Oxford, Blackwell, 1976, p. 177.

${ }^{22}$ J. E. Buikstra and D. C. Cook, 'Pre-Columbian tuberculosis: an epidemiological approach', MCV/Quart., 1978, 14, 1: 32-44.

${ }^{23} \mathrm{R}$. H. Hilton, The English peasantry in the later Middle Ages, Oxford, Clarendon Press, 1975. 


\section{Tuberculosis and leprosy in antiquity}

Leprosy, too, is a chronic infective disease by bacteria of the genus Mycobacterium. Unlike Mycobacterium tuberculosis, Mycobacterium leprae is a single species without types. The different clinical manifestations of leprosy are due, not to bacterial variety, but to the differing immune status of individual patients. At one end of the immunity spectrum is the low resistance to the infection, resulting in lepromatous leprosy; at the other, is the high resistance to infection resulting in tuberculoid leprosy. Between these extremes are the borderline types. Lepromatous leprosy is the most severe and most infectious type, with the most widespread bodily involvement. Tuberculoid leprosy, although producing nerve impairment and skin change, is the least damaging and the least infectious type. In addition to these groups of manifest clinical leprosy, there are individuals infected with the bacilli who do not develop the clinical signs of the disease. This is the so-called subclinical leprosy. It is now realized that Mycobacterium leprae is a highly infective bacterium but one which is of low pathogenicity; that is, its ability to induce clinical disease is low. The incidence of subclinical leprosy is probably high. Although lepromatous leprosy is the most infectious form and tuberculoid leprosy the least infectious, the infectivity of borderline, tuberculoid, and even subclinical leprosy should not be totally forgotten. These forms may have been of relevance in the medieval spread of the disease.

Browne $^{24}$ has suggested that lepromatous leprosy was the form of significance in the past. Although the writings of contemporary physicians in earlier populations are imprecise by modern medical standards, Dols ${ }^{25}$ has suggested that the other forms of leprosy were certainly known and recognized in the past. Paul of Aegina, a Byzantine physician, did, he suggests, distinguish lepromatous leprosy from the milder tuberculoid leprosy. Since a genetic factor in the immunity of leprosy is, if it exists at all, of very minor importance, there is no reason why all forms of leprosy known in modern clinical contexts should not have existed in antiquity.

The bone changes of leprosy have been analysed by $\mathbf{M} \phi$ ller-Christensen ${ }^{26,27}$ subsequent to his excavation of the cemetery of the medieval leprosarium at Naestved, Denmark. This work has been reinforced and comparative analysis carried out by Schmitz-Cliever ${ }^{28}$ following the excavation at Melaten. There appear, however, to be some regional differences.

Briefly, the skeletal changes of leprosy are found around the oral and nasal cavities and at the limb extremities. The cranial features, the so-called facies leprosa, consist of the progressive erosion of the alveolar process of the maxilla with the loosening and ultimate loss of the central and lateral maxillary incisor teeth. There is an associated erosion of the anterior nasal spine leading to its ultimate loss. The margins of the pyriform aperture become eroded at their lower parts. Both the nasal and the oral surfaces of the palatine process of the maxilla exhibit inflammatory changes, and there may ultimately be perforation of the hard palate. These rhinomaxillary changes of facies leprosa are inflammatory and are due specifically to the action of the leprosy

24 S. G. Browne, 'How old is leprosy?', Br. med. J., 1970, 3: 640-641.

${ }^{25}$ M. W. Dols, 'Leprosy in medieval Arabic medicine', J. Hist. Med., 1979, 34: 314-333.

${ }^{26} \mathrm{~V}$. Mфller-Christensen, Bone changes in leprosy, Copenhagen, Munksgaard, 1961.

${ }^{27}$ V. Mфller-Christensen, Leprosy changes of the skull, Odense University Press, 1978.

${ }^{28}$ E. Schmitz-Cliever, 'Zur Osteoarchäologie der mittelalterlichen Lepra', Med. hist. J., 1973, 8: $182-200$. 


\section{K. Manchester}

bacillus. They are found only in the low resistant lepromatous form of the disease.

The postcranial features are not due specifically to the leprosy bacillus but are probably the sequelae of secondary bacterial infection resulting from the ulceration of the anaesthetic leprous extremities. The lower limb changes are characteristically gross periostitis of the tibiae and fibulae, usually bilateral, and commencing at the distal ends. There is inflammatory change in the distal foot commencing in the metatarsals, and there may be inflammatory change in the tarsal bones. These metatarsals develop concentric atrophy and become pencil-shaped with the loss of medullary cavity. The phalanges are lost. In the hands, the inflammatory change commences in the phalanges, spreading later to the metacarpal bones. These changes result from trauma to the anaesthetic fingers, and are sometimes associated with the claw-hand deformity of leprous paralysis. There are other less common skeletal, dental, and radiological manifestations of leprosy, but further discussion is beyond the scope of the present paper.

Although Andersen ${ }^{29}$ cites literary references to leprosy in early India, and GweiDjen and Needham, ${ }^{30}$ and Skinsnes ${ }^{31}$ have produced literary evidence suggesting that it was already established in China during the first millennium BC, the earliest corporate evidence of leprosy is from the Dakhleh Oasis in Egypt. A Ptolemaic Period cemetery contained the skeletons of four adult males of European type of the second century BC. Dzierzykray-Rogalski ${ }^{32}$ diagnosed leprosy on the features of facies leprosa, and has suggested that these Europeans in a predominantly negroid burial ground possibly represented lepers segregated from the Ptolemaic capital because of their disease. If, in fact, segregation was practised at this early time, this is evidence for a knowledge of leprosy in the society for some considerable time before. And yet, to date, no other leprous skeletons have been recorded from this period. But neither have leprous skeletons been recorded from India or from China, the areas which, from documentary evidence, may be the cradle of the disease.

Andersen ${ }^{29}$ has proposed that leprosy was brought back from the Indo-Gangetic Basin by the returning armies of Alexander the Great in 327-326 BC. This is obviously a convenient and clear event, but may be simplistic, particularly since mercantile caravans may have been travelling the routes regularly and for some time previous. However, Dols ${ }^{25}$ states that "There is no persuasive evidence that true leprosy occurred in ancient Egypt, Mesopotamia, or Persia before the time of Alexander the Great."

After the Dakhleh specimens, there is a gap of some 500 years before further skeletal evidence is found. Adequate clinical descriptions of lepromatous leprosy did appear during this period, the best perhaps by Aretaeus of Cappadocia, a contemporary of Galen in the second century AD. But there is no osteoarchaeological

\footnotetext{
29 J. G. Andersen, Studies in the mediaeval diagnosis of leprosy in Denmark, Copenhagen, Costers Bogtrykken, 1969.

${ }^{30} \mathrm{Lu}$ Gwei-Djen and J. Needham, 'Records of diseases in ancient China', in D. Brothwell and A. T. Sandison (editors), Diseases in antiquity, Springfield, III., Charles C Thomas, 1967, pp. 222-237.

${ }^{31} \mathrm{O}$. K. Skinsnes, 'Leprosy in archaeologically recovered bamboo book in China', Int. J. Leprosy, 1980, 48: 333.

${ }^{32}$ T. Dzierzykray-Rogalski, 'Palaeopathology of the Ptolemaic inhabitants of Dakhleh Oasis (Egypt)', $J$. hum. Evol., 1980, 9: 71-74.
} 


\section{Tuberculosis and leprosy in antiquity}

evidence as yet. Møller-Christensen and Hughes $^{33}$ made the diagnosis on facies leprosa in a skull of the late fourth century AD. Elliot Smith ${ }^{34}$ also diagnosed the disease in a mummy of the same period. Both of these specimens came from El Biga in Nubia. Reader ${ }^{35}$ has diagnosed leprosy in a skeleton from Poundbury, dated to AD 400. This diagnosis was made on the feet and lower legs only, the remainder of the skeleton unfortunately being unavailable for study. The diagnosis has also been made by Wells ${ }^{36}$ on the lower limb changes in a male skeleton from Beckford, Gloucestershire, of sixth century AD date; and by M $\phi$ ller-Christensen and Hughes ${ }^{37}$ on both cranial and postcranial features in a male skeleton from Burwell, Cambridgeshire, of the seventh century AD. A further specimen of seventh-century date has been reported by Brothwell. ${ }^{38}$ This male specimen from Tean, Isles of Scilly, exhibited both cranial and postcranial features of leprosy. The source of infection of this geographically isolated case was probably mainland Britain.

Quite possibly, then, leprosy was transferred from the Mediterranean littoral to Britain by the Roman Conquest, either by the militia itself or by the increased mercantile traffic consequent upon the Conquest. What should be remembered, however, is that the person transporting the leprosy bacterium and infecting the indigenous Briton may not have had manifest lepromatous leprosy during his northward journey. The incubation period of leprosy is five to ten years, so an individual in this symptomless phase could easily have travelled from the Mediterranean to Northern Europe undetected, developing symptoms after arrival. There is also the additional factor of infectivity during the incubation period. It is quite probable that the individual incubating leprosy but without, as yet, manifest signs is capable of transmitting the disease to others. Alternatively, although lepromatous leprosy is the most infectious form, the infectivity of tuberculoid leprosy and borderline leprosy is not negligible. These forms lack the mutilating features of lepromatous leprosy, and the afflicted could easily have travelled the country freely, passing on their dread disease.

Further specimens of leprous skeletons are known from pre- and post-Norman Conquest Britain, but the number is not great, perhaps only fifteen to twenty cases to the end of the Middle Ages. Against this rather meagre osteoarchaeological evidence is the abundant evidence of the lazar house foundations. From a foundation of three in the last half of the eleventh century, the number reached some fifty-three in England in the first half of the thirteenth century (Fig. 1). Using this evidence, it seems that at that time, leprosy in England was at its peak, requiring some 200 lazar houses for the care of its victims. Thereafter, the number of lazar hospital foundations decreased

${ }^{33} \mathrm{~V}$. Mфller-Christensen and D. R. Hughes, 'An early case of leprosy from Nubia', Man, 1966, 1: 242-243.

${ }^{34}$ G. Elliott Smith, 'Anatomical report', Bull. archaeol. Surv. Nubia, 1908, 1.

${ }^{35} \mathrm{R}$. Reader, 'New evidence for the antiquity of leprosy in early Britain', J. archaeol. Sci., 1974, 1: 205-207.

${ }^{36}$ Calvin Wells, 'A possible case of leprosy from a Saxon cemetery at Beckford', Med. Hist., 1962, 6: 383-386.

${ }^{37} \mathrm{~V}$. Mфller-Christensen and D. R. Hughes, 'Two early cases of leprosy in Great Britain', Man, 1962, no. 287: 177-179.

${ }^{38} \mathrm{D}$. Brothwell, 'The palaeopathology of early British man: an essay on the problems of diagnosis and analysis', J. R. Anthrop. Inst., 1961, 91: 318-344. 


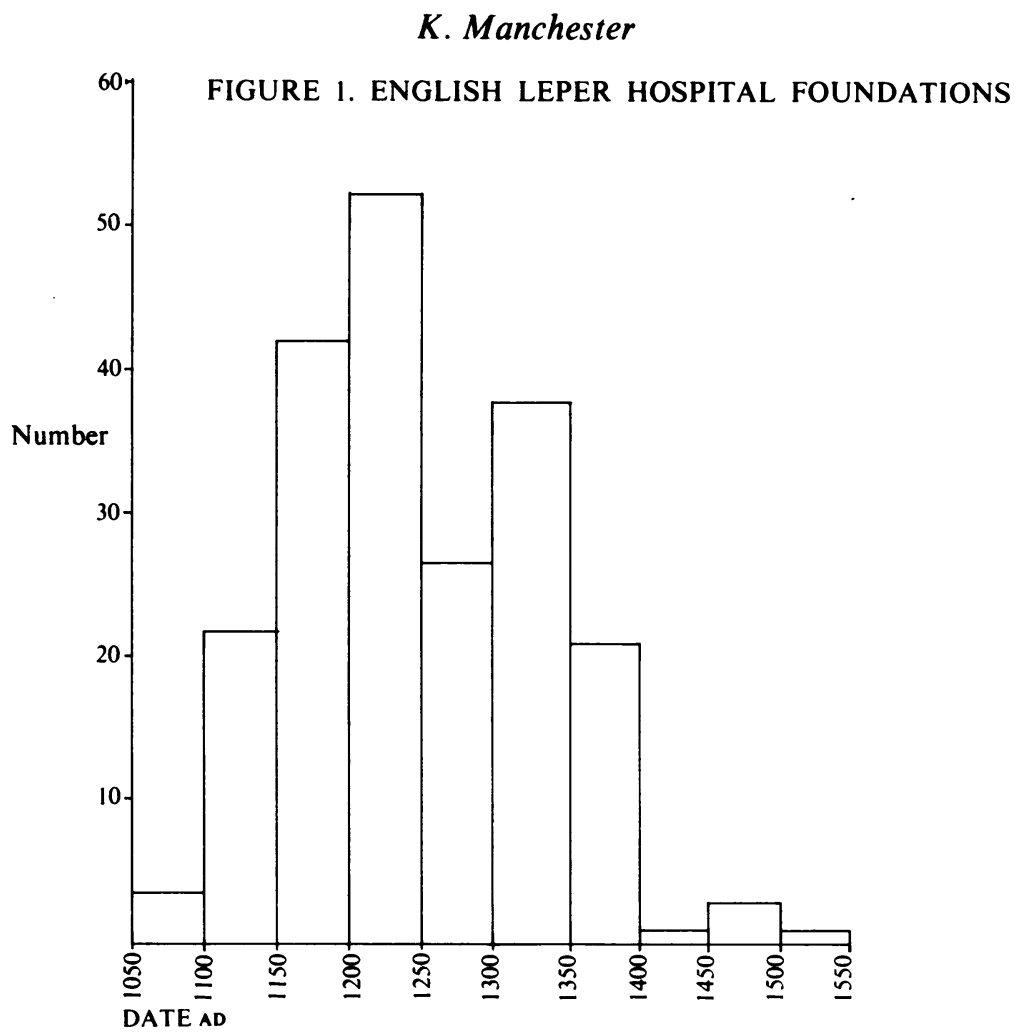

(Source of figures: R. M. Clay, The mediaeval hospitals of England, London, Frank Cass, 1966.)

rapidly. Richards ${ }^{39}$ states that the disease was rare in fifteenth-century England, and by the sixteenth century was virtually unknown. Clearly, even if the leprosy incidence continued to increase in the later Middle Ages, lazar hospitals would not continue to abound. Surely, a saturation point of care institutions would be reached, at which time the need for more institutional places would level off. It may not be totally justifiable, therefore, to use lazar hospital foundation dates as evidence of leprosy rise and fall. Significantly, the leprous skeletons from pre-Conquest England have been found in general cemeteries. There seems to have been no distinction in death. It is likely, therefore, that there was no distinction or segregation, leper from non-leper, in life in Anglo-Saxon England. This is in contrast with Ptolemaic Egypt, according to the evidence of Dzierzykray-Rogalski. ${ }^{32}$ It may be that the post-Conquest lazar hospitals also accepted an increasing number of non-leprous inmates. That they were not exclusively for lepers is attested by their composition. For example, St Giles' Hospital, Norwich, had in its establishment a master, eight chaplains, two clerks-in-holy-orders, seven choristers, two sisters, and eight lepers. This may represent the extreme, but the Hospital of St Mary Magdalene at Lynn provided for a prior and twelve brethren or sisters, some of whom were to be whole and some leprous. St Bartholomew's at Oxford contained two whole and six infirm or leprous inmates. To these regulations concerning the afflicted must be added the possibility of diagnostic error.

${ }^{39} \mathrm{P}$. Richards, The mediaeval leper and his northern heirs, Cambridge, D. S. Brewer, 1977. 


\section{Tuberculosis and leprosy in antiquity}

In the Middle Ages, the diagnosis and consequent segregation of the leper was the responsibility of the local church and village elders. Clinical precision was unknown at that time. However, Møller-Christensen ${ }^{27}$ found that seventy per cent of the skeletons from Naestved had changes positively diagnostic of leprosy. The excavation comprised some 500 skeletons from the cemetery of the hospital which was operative in AD 1250-1550. If similar figures are appropriate for England, then the degree of medieval diagnostic accuracy was good. If it is accepted that the remaining thirty per cent of unaffected skeletons may represent some individuals with leprosy in its early stage before bone involvement, in addition to the non-leprous inmates and staff, then certainly the incidence of the disease was higher than implied by Creighton's suggestion that lepers were no more numerous than the village idiots, whatever they might be. An additional factor in this respect is the finding by $\mathrm{Job}^{40}$ that, although leprosy bacilli may be found in the bone marrow of cases of lepromatous leprosy, only a small percentage of them develop destructive bone lesions. In modern clinicopathological investigations, Faget and Mayoral ${ }^{41}$ found bone changes in twenty-nine per cent of 505 cases of leprosy, and Paterson ${ }^{42}$ reported such changes in fifty-four per cent of 894 cases in a Hong Kong leprosarium. Therefore, leprosy may have been much more prevalent than the osteoarchaeological evidence attests if, that is, the relative incidence of bone change was the same in antiquity as it is today. Regrettably, it is doubtful if proof of this latter hypothesis will ever be forthcoming. Assuming that only fifty-four per cent of lepers exhibited bone changes, if the medieval policy of leprous segregation was absolute, there should not be more than fifty-four per cent of the skeletons in leprosaria cemeteries with bone changes. The figures from M $\phi$ ller-Christensen's research at Naestved raise the interesting possibility that not all lepers were segregated in medieval Denmark. It is possible, but conjectural, that only the severely affected lepers with obvious bone changes were isolated.

But, notwithstanding all the problems of evidence for this highly emotive medieval disease, there can be little doubt that it disappeared almost as quickly as it came to prominence, the whole during a period of some 500 years. The credit for this control has customarily been given to the medieval policy of segregation. Although this may have been a contributory factor, it may not have been great. During the late nineteenth-century decline of leprosy in Norway, it is noted that few sufferers were in hospital, and their number was fairly constant even during the most rapid phase of decline (Fig. 2). Also, the isolation of lepers was not absolute in the Middle Ages; they were allowed out of the lazar houses to beg for alms, thereby having some contact with the healthy population. The lepromatous form of the disease is, as already stated, highly infectious. Quite possibly, many individuals with tuberculoid leprosy and borderline leprosy (lacking the mutilating stigmata of lepromatous leprosy) may not have been segregated at all. They may have continued their infectious way in the community, but it must be remembered that the infectivity of these forms is low when compared with lepromatous leprosy. In addition, infected individuals would certainly

${ }^{40}$ C. K. Job, 'Pathology of leprous osteomyelitis', Int. J. Leprosy, 1963, 31: 26-33.

${ }^{41} \mathrm{G}$. H. Faget and A. Mayoral, 'Bone changes in leprosy: a clinical and roentgenological study of 505 cases', Radiology, 1944, 42: 1-13.

${ }^{42}$ D. E. Paterson, 'Bone changes in leprosy. Their incidence, progress, prevention and arrest', Int. J. Leprosy, 1961, 29: 393-422. 


\section{K. Manchester}

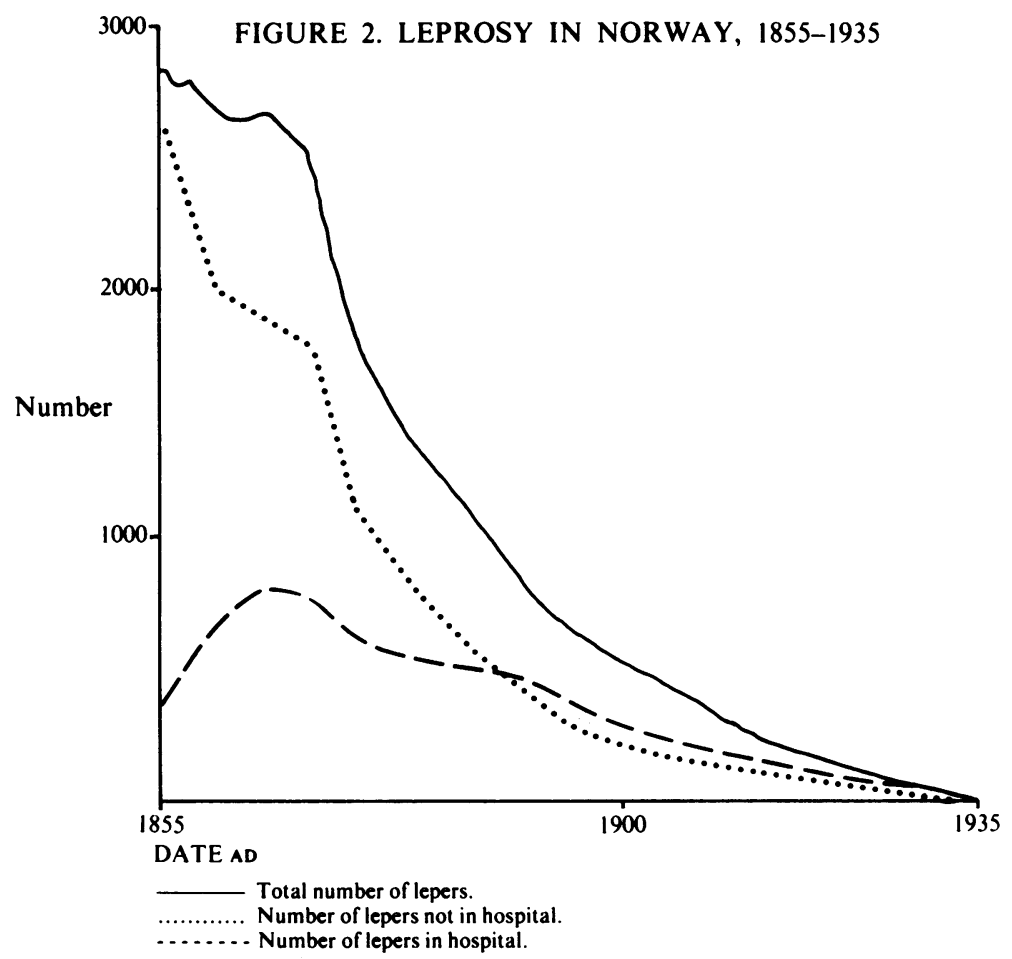

(Compiled from P. Richards, The mediaeval leper and his northern heirs, Cambridge, D. S. Brewer, 1977.)

not have been segregated during their incubation period, and yet they were capable of spreading the disease.

It is considered highly significant that coincident with this medieval decline of leprosy was the rise in incidence of tuberculosis. The reasons suggested for this significance are in part pathological, in part clinical, and in part palaeopathological.

First, both diseases are caused by Mycobacterium, a single genus, and Lurie ${ }^{43}$ has shown that the actual tissue response provoked by the two bacteria Mycobacterium tuberculosis and Mycobacterium leprae is essentially the same. The immune response of people to infection is similar for the two diseases. Following the initial work by Chaussinand, ${ }^{44}$ Jopling, ${ }^{45}$ Lowe and McNulty ${ }^{46}$ observe that BCG vaccine, a vaccine prepared specifically for inoculation against tuberculosis, is of benefit in the prevention of leprosy in some communities. In other words, there is a degree of crossimmunity between tuberculosis and leprosy. Chaussinand ${ }^{44}$ and Grmek ${ }^{47}$ remark that the individual affected by tuberculosis seems to benefit to a certain extent from a

${ }^{43}$ M. B. Lurie, 'A pathogenetic relationship between tuberculosis and leprosy: the common denominators in the tissue response to mycobacteria', in Ciba Foundation Symposium on Experimental Tuberculosis, Boston, Mass., Little, Brown, 1955, pp. 340-343.

4 R. Chaussinand, La lèpre, Paris, Expansion Scientifique Française, 1955.

45 W. H. Jopling, Handbook of leprosy, London, Heinemann, 1978.

$46 \mathrm{~J}$. Lowe and F. McNulty, 'Tuberculosis and leprosy: immunological studies in healthy persons', Br. med. J., 1953, ii: 579-584.

${ }^{47}$ M. D. Grmek, 'Préliminaires d'une étude historique des maladies', Annales: Economies, Sociétes, Civilisations, 1969, 24: 1473-1483. 


\section{Tuberculosis and leprosy in antiquity}

protection against leprous infection. In leper hospitals in recent times, pulmonary tuberculosis has been the single major cause of death. Tuberculosis, therefore, will develop in the leper, and Rogers and Muir ${ }^{48}$ conclude that leprosy does not produce any immunity against tuberculosis. Following the medical supervision of 500 leprous patients, Jopling ${ }^{49}$ recorded that no patient gave a past history of tuberculosis, but three patients developed tuberculosis after the onset of leprosy.

Both leprosy and tuberculosis are infectious diseases, which are usually contracted at a very early age. Leprosy today is contracted during the nursing period, only to manifest itself after the relatively long incubation period of five to ten years. There is no reason to suppose that the age of leprous contraction in antiquity was any different. Primary tuberculous infection, that stage inducing an immune response, also occurs in childhood. In earlier peoples, it is likely that tuberculous contraction would have occurred in infancy, either from tuberculous milk or from the overt tuberculous adult. Dubos $^{50}$ comments that tuberculosis is rarely severe in children between the ages of five and twelve years, and that contact with tubercle bacilli during that period provides immunity to later infection. Such abortive infections led progressively to the development of a partially immune population. At present, there is only one example known from antiquity of these two diseases co-existing in the same specimen. Weiss and Møller-Christensen ${ }^{51}$ demonstrated chronic pulmonary tuberculosis in a lepromatous leper from medieval Denmark. It seems, then, that tuberculous infection in an individual may reduce the likelihood of subsequent infection by the leprosy bacillus.

In summary, therefore, the increased tuberculous infection in the community, probably of the human-type pulmonary lesions, induced an immunity in the survivors which prevented the superinfection by the allied Mycobacterium leprae. In the past, just as today, the majority of individuals, mostly young children, would overcome the primary tubercle invasion, would recover, and would henceforth be immune to leprosy. Pulmonary tuberculosis, being a population density-dependent disease, owes its medieval increase to urbanization or at least to the development of aggregate population groups. Both diseases, therefore, may owe their changing incidence in medieval England to a phenomenon of human social development.

Leprosy affects an estimated twelve to fifteen million people today, and tuberculosis is also very prevalent. That they were of collective and individual significance in earlier communities is without question. It is proposed that these two infectious diseases were closely interrelated in antiquity.

${ }^{48}$ L. Rogers and E. Muir, cited in Chaussinand, op. cit., note 44 above.

${ }^{49}$ W. H. Jopling, 'Clinical aspects of leprosy', Tubercle, 1982, 63: 295-305.

so R. Dubos and J. Dubos, The white plague, Boston, Mass., Little, Brown, 1952, p. 190. Grmek (1983), op. cit., note 8 above, pp. 297-300.

${ }^{31}$ D. L. Weiss and V. Mфller-Christensen, 'An unusual case of tuberculosis in a mediaeval leper', Dan. med. Bull., 1971, 18: 11-14. 